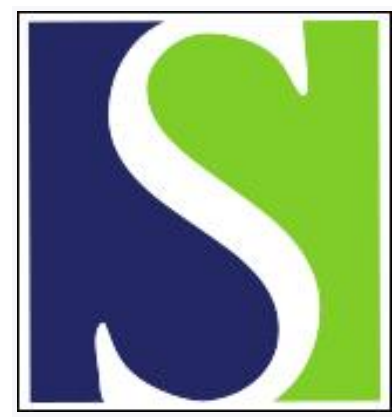

Scand J Work Environ Health 2014;40(4):370-379

https://doi.org/10.5271/sjweh.3429

Published online: 09 Apr 2014, Issue date: 01 Jul 2014

Full- and part-time work: gender and welfare-type differences in European working conditions, job satisfaction, health status, and psychosocial issues

by Bartoll X, Cortès I, Artazcoz L

1. Job dissatisfaction among female part-time workers from southern Europe are explained by their poorer working conditions. However, part-time work is associated with better health outcomes for all welfare state regimes. 2. Being in part-time employment in continental and southern Europe, respectively, is associated with poorer health outcomes among men, even after controlling for working conditions. 3 . Since the frequency of part-time tends to increase, effective measures to ensure equal treatment between fulland part-time workers should mark the next labor policy agenda.

Affiliation: Agència de Salut Pública de Barcelona, PI Lesseps 1, 08023 Barcelona, Spain. xbartoll@aspb.cat

Refers to the following texts of the Journal: 2003;29(6):444-451 2013;39(4):369-378

The following article refers to this text: 2021;47(8):591-599

Key terms: European Working Conditions Survey; full-time work; gender; health status; job satisfaction; part-time work; psychosocial issue; psychosocial work environment; socioeconomic factor; stress; welfare state

This article in PubMed: www.ncbi.nlm.nih.gov/pubmed/24718633

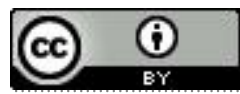




\title{
Full- and part-time work: gender and welfare-type differences in European working conditions, job satisfaction, health status, and psychosocial issues
}

\author{
by Xavier Bartoll, MPH, 1, 2, 4 Imma Cortès, MPH, 1, 2, 4 Lucía Artazcoz, PhD 1, 2, 3, 4
}

\begin{abstract}
Bartoll X, Cortès I, Artazcoz L. Full- and part-time work: gender and welfare-type differences in European working conditions, job satisfaction, health status, and psychosocial issues. Scand J Work Environ Health. 2014;40(4):370-379. doi:10.5271/sjweh.3429
\end{abstract}

\begin{abstract}
Objectives The aim of this study was to analyze the differences between full- and part-time employment (FTE and PTE) in terms of working conditions, on the one hand, and job satisfaction, health status, and work-related psychosocial problems according to gender and welfare state regime, on the other hand, and to analyze the role of working conditions in the association between PTE and FTE.
\end{abstract}

Methods This cross-sectional study was based on a sample of 7921 men and 8220 women from the European Working Conditions Survey aged 16-64 years, who were employed part-time (5-19 or 20-30 hours per week) or full-time (31-40 hours/week). Multiple logistic regression models were fitted separately for each gender and welfare state regime.

Results PTE is associated with poorer working conditions than FTE for all national welfare types. Among women, only those in southern European countries experienced low job satisfaction [odds ratio after adjustment $\left(\mathrm{OR}_{\mathrm{adj}}\right)$ for sociodemographic variables, $\mathrm{OR}_{\mathrm{adj}} 1.73$, and 1.66, for those working 20-30 and 5-19 hours/ week, respectively; reference group: FTE workers], but this association disappeared after further adjustment for working conditions. Low job satisfaction and poorer health status was more common among PTE men from continental (low job satisfaction, $\mathrm{OR}_{\mathrm{adj}} 1.80$ and 3.61, for 20-30 and 5-19 working hours/week, respectively), and southern European $\left(\mathrm{OR}_{\mathrm{adj}}, 2.98\right.$, for 5-19 working hours/week) countries. PTE tended to be associated with fewer psychosocial problems among women, but with more psychosocial problems among men in continental Europe and those those engaged in "mini-jobs" in southern European welfare regimes.

Conclusions The association between FTE and PTE and job satisfaction, health status, and psychosocial problems is partly driven by working conditions and differs between gender and welfare regime. This highlights the importance of promoting effective measures to ensure equal treatment between FTE and PTE workers and the role of the social norms that form part of these different welfare states regimes.

Key terms Europe; full-time work; psychosocial work environment; stress; socioeconomic factor; welfare state.

The increase in the frequency of part-time employment (PTE) has been related to two main causes: first, the massive incorporation of women into the labor market to facilitate family life, and second, the increasing demand for a more flexible work force since the 1980s, in the context of high mobility financial flows, industrial relocation, and international competition tied to the business cycle (1). PTE has been growing steadily more common since then, reaching $18.9 \%$ of the employed population in the the 27 member states of the European Union (EU-27) in the fourth quarter of 2011, with significant differences between sexes (31.7\% among women and 8.1\% among men) (2). The reasons for working part-time are likely to differ markedly between genders, with men generally doing so because they are in training and women due to family obligations. These gender distinctions in the motivation for being in PTE may be the result of differences in working patterns between genders, which may in turn result in differences in working conditions and the association between employment and health status (3).

The frequency of PTE also differs markedly between countries, from $48.8 \%$ in the Netherlands $(25.4 \%$ men, $76.7 \%$ women), to a moderate $13.7 \%$ in Spain ( $6.0 \%$ men, $23.5 \%$ women ) and minimal $2.1 \%$ in Bulgaria $(2.2 \%$ men,

1 Agència de Salut Pública de Barcelona, Barcelona, Spain.

2 CIBER en Epidemiología y Salud Pública (CIBERESP), City, Spain.

3 Universitat Pompeu Fabra, Barcelona, Spain.

4 Institute of Biomedical Research (IIB-Sant Pau), Barcelona, Spain.

Correspondence to: Sr. X Bartoll, Agència de Salut Pública de Barcelona, Pl Lesseps 1, 08023 Barcelona, Spain. [E-mail: xbartoll@aspb.cat] 
$2.6 \%$ women) (2). It has been suggested that a country's welfare state regime shapes the gender division in family caregiver and breadwinner roles, as well as the type of family-friendly policies that determine to a great extent the influence of the work-family combination on health and well-being $(4,5)$. PTE-associated working conditions may differ between national welfare state regimes, which may modulate the impact of PTE on health.

Despite the empirical relevance of gender and welfare differences in PTE, most studies have focused on the effects of different forms of job flexibility on health status (6), and employment conditions such as differences in wages and promotion opportunities between PTE and full-time employment (FTE) (7-9), but without fully exploring these differences in psychosocial working conditions as a function of gender and welfare regime. Previous literature dealing with PTE found contradictory results. In their review on precarious employment, Quinlan et al (10) did not observe a clear association between poor health and job insecurity involving PTE. In a study based on the working population in Europe, Benavides et al (11) reported a link between type of work contract and psychosocial problems and physical health, and concluded that people with PTE experience less work-related stress but have poorer job satisfaction than those in FTE, although these authors did not consider gender differences. In their systematic review, Joyce et al (12) found one study where having an involuntary part-time contract was associated with depression (13). More recently, studies by Rodriguez (14) and Bardasi (15) on atypical employment generally found no association between PTE and health, quality of life outcomes and job satisfaction, although they did notice some gender differences.

The objectives of this study were to analyze the differences between PTE and FTE in terms of working conditions, on the one hand, and job satisfaction, health status, and work-related psychosocial problems according to gender and welfare state regime, on the other hand, and to analyze the role of working conditions in the association between PTE and FTE.

\section{Methods}

Data were obtained from the $4^{\text {th }}$ European Working Conditions Survey (EWCS) carried out in 2005 (16). This survey was representative of the employed population and conducted using a multistage, stratified and clustered design with a "random walk" procedure. Ineligible cases (35.4\%) included vacant housing units, housing units with no workers, and those that were not residences. The refusal rate among eligible units was $24 \%$ and contact was not made with $9.4 \%$ of eligible units. These sample units were replaced until the target number of interviews was achieved. Details of the survey are reported elsewhere (17). For the purpose of this study, we selected a sub-sample of EU-27 employees aged 16-64 years who worked $\leq 40$ hours/week. We excluded those who reported that they were self-employed due to their more irregular working hours, and to avoid "marginal part-time", we excluded those who worked $<5$ hours/week. In total, 16141 individuals (7921 men and 8220 women) were included in the final analysis, of whom 12379 were in FTE and 3762 PTE, and of whom 1317 (329 men and 988 women) worked 5-19 hours/week and 2445 (452 men and 1993 women) 20-30 hours/week. Weights were applied to restore the representativeness of each of the EU-27 countries' employed populations.

\section{Measurements}

Full- and part-time employment. The working hours variable was based on the question, "How many hours do you work per week in your main job?", with an open response indicating the number of working hours/week. Individuals who worked $\leq 30$ hours/week were defined as being in PTE $(18,19)$, and were divided into two categories: 5-19 hours/week and 20-30 hours/week. Individuals who worked 31-40 hours/week were defined as being in FTE (the reference category).

Working and employment conditions. We used the Karasek-Theorell-Johnson (20) psychosocial risk model to assess the psychological demands of work, personal control over work activity, and social support from peers. We also accounted for two components of the Siegrist effort-reward model (21), salary and promotion, and type of contract as employment conditions. To facilitate interpretation of the results, all working and employment conditions were coded to allow for direct comparison between adverse and non-adverse working conditions.

Psychosocial working conditions. To assess psychological demands and control we followed the methodology used in previous publications (22). The psychological demands variable was constructed from two factors, working at high speed and working with deadlines, both on a 7-point scale. Individuals who fell below and above the median of this scale were defined as having "low" and "high" work demands, respectively (Cronbach's alpha 0.7 , reference category: low demands).

A similar process was followed to construct the personal control variable from ten questions with various response categories: authorization to (i) decide the schedule, (ii) choose or change the order of tasks, (iii) select the methods and (iv) the speed of the work, (v) solve unforeseen problems autonomously, (vi) incorporate new knowledge, (vii) influence the choice of 
working partners, (viii) take a break when desired, (ix) choose when to take leave, and (x) apply one's own ideas at work. This variable was expressed as the number of affirmative answers on a scale of $0-10$, and then dichotomized about its median, with individuals below and above the median defined as having "low" and "high" personal control over their work, respectively (Cronbach's alpha 0.7; reference category: high control).

The level of social support received from peers was appraised through workers' responses to the question, "Can you get assistance from colleagues if you ask for it?", with answers on a 5-point scale (1-5, ranging from "almost always" to "almost never") being dichotomized about its median, and individuals below and above the median defined as having "low" and "high" support, respectively (reference category: high support).

Wage, promotion and employment conditions. Wage compensation and promotion issues were assessed using the statements: "I am well paid for the work I do" and "My job offers good prospects for career advancement", respectively, with responses on a 5-point scale (1-5, ranging from "strongly disagree" to "strongly agree"), being dichotomized about its median, and individuals falling above and below the median on each scale being defined as having a "high" and "low" salary (reference category: high salary), or "high" and "low" possibility of promotion (reference category: high possibility of promotion), respectively. For employment conditions, we considered two types of contract, permanent (reference category) and temporary, the latter including fixed-term, temporary agency contract, learning, and no contract.

For simplicity, we hereafter refer to working and employment conditions simply as working conditions.

Job satisfaction. This was evaluated using the question, "On the whole, are you very satisfied, satisfied, not very satisfied or not satisfied with the working conditions in your main paid job?" This variable was dichotomized by combining the categories "very satisfied" and "satisfied" to indicate satisfaction, and the categories "not very satisfied" and "not satisfied" to indicate low satisfaction.

Health status and work-related psychosocial problems. We examined the work effect on health status, and two measures of psychosocial problems: stress and psychosocial distress. The effect of work on health status was measured as a dichotomous variable using the question, "Does work affect your health or not?" (with no stress as the reference category). According to the questionnaire's design, this question acts as a filter for a series of health problems, from which two symptoms of psychosocial problems where considered: stress and psychological distress. Stress was expressed as a dichotomous variable (experienced stress or not, with the former as the reference category), and the validity of this single-item measure of stress has previously been demonstrated (23). Psychological distress was defined as having one or more of the following symptoms: general fatigue, sleep problems, anxiety, and irritability (having none of these was the reference category) (Cronbach's alpha 0.6).

Typology of welfare state regime. Countries were grouped by region according to an adaptation of the EspingAndersen (24) definition of welfare state regimes, which was expanded to include all countries covered by this survey (25), similar to that used by Eikemo et al (26). Countries were grouped as follows: (i) Scandinavia and The Netherlands: Sweden, Norway, Denmark, Netherlands; (ii) Continental Europe: Belgium, Germany, France, Luxembourg, Austria; (iii) Southern Europe: Italy, Spain, Greece, Portugal, Cyprus, Malta; (iv) Eastern Europe: Czech Republic, Estonia, Latvia, Lithuania, Hungary, Poland, Slovakia, Slovenia, Bulgaria, Romania; and (v) Anglo-Saxon countries: Ireland and United Kingdom.

Sociodemographic characteristics. Interviewees were asked about personal and household characteristics: sex was directly coded, age with the question "Starting with yourself, how old are you?", expressed as a continuous variable. Data on marital status (married/ cohabiting or not) and having children aged $\leq 3$ years or not, were taken from grid questions of all household members' relationships and ages. Job category was defined according to the International Standard Classification of Occupations 1988 (ISCO-88) 1-digit classification in three levels: upper (1-3), middle (4-6), and lower (7-9) category.

\section{Data analysis}

First, we analyzed gender differences according to regional typology for all variables (chi-square test for categorical variables and Student's t-test for age). Second, we calculated the association between individuals in PTE and FTE with adverse versus non-adverse working conditions. For each analysis, we calculated odds ratios (OR) and $95 \%$ confidence intervals $(95 \% \mathrm{CI})$ by fitting logistic regression models adjusted for sociodemographic characteristics. Third, we followed the same approach for the analysis of the association between individuals in PTE and FTE with low job satisfaction, health and psychosocial problems affected by work compared to the reference categories, high job satisfaction, and not having health and psychosocial problems affected by work. Fourth, we fit a final model equivalent to the previous one, but with additional adjustment for working conditions. We also used the Wald test to assess the presence of linear trends in the above associations. 
All models included weights derived from the complex sample design and were stratified by gender and region.

\section{Results}

\section{General description of the sample}

A general description of the study sample stratified by sex and region is shown in table 1. For all regions, the prevalence of PTE was higher among women, both among those who work 20-30 and 5-19 hours/week (the only exception was among people from Eastern Europe who worked 5-19 hours/week). The lowest prevalence of women in PTE was observed in Eastern Europe, and the highest in the Anglo-Saxon countries, especially among those who work 5-19 hours/week (24.0\%). The psychological demands of work were greater for men, especially in Southern Europe (52.5\% men and 37.5\% women). The degree of personal control over work activity and peer support was generally quite homogeneous between sexes and regions, except in Scandinavia and The Netherlands, where women generally had less control than men.

We observed a clear pattern of lower salaries and a lower chance of promotion for women than men in most regions, except in Southern Europe, where salaries and promotion possibilities were equally low for both sexes. Women in Southern Europe were more likely than men to have non-permanent contracts, while men from the Southern and Eastern European regions were more likely than women to be dissatisfied with their jobs.

Gender differences for job satisfaction were only observed in Southern (men 27.6\%; women 21.3\%) and Eastern (men 24.3\%; women 19.5\%) Europe.

\section{Differences in working conditions}

The results of this analysis are shown in table 2, from which we highlight several points. First, with regard to psychosocial working conditions, PTE women had lower job demands compared to FTE in all regions, and a gradient was observed between the job's demands and the length of working hours (except in the Eastern Europe region). Among men, we observed a mixed picture: those in Scandinavia and The Netherlands who work the least hours had the lowest demands, while those in Continental Europe who work 5-19 hours/week had the highest job demands $\left(\mathrm{OR}_{\text {adj }} 2.89,95 \%\right.$ CI 1.79-4.66). Men generally had less control over their work activity, mainly those working 5-19 hours/week, while women working PTE and men working 5-19 hours/week from Southern Europe had the least peer support. Second, with regard to adverse employment conditions, PTE workers of both sexes and in all regions mostly commonly had a non-permanent contract and poor chances of promotion. The association between PTE and having a non-permanent contract was strongest in Southern and Eastern Europe in both sexes, and we observed a gradient between length of working hours and chances of promotion among women in all regions. Third, of all regions, the worst PTE working conditions were observed in Southern Europe among both sexes (with a gradient in relation to the length of working hours in most cases) and Anglo-Saxon males. In contrast, PTE women in Scandinavia and The Netherlands had better working conditions, with only low chances of promotion associated with PTE.

Differences in job satisfaction, health status, and psychosocial problems related to work

As shown in table 3, only in Southern Europe did PTE women experience low job satisfaction (20-30 hours/ week, $\mathrm{OR}_{\text {adj }} 1.73,95 \%$ CI 1.31-2.77; 5-19 hours/week, $\mathrm{OR}_{\text {adj }} 1.66,95 \%$ CI 1.08-2.54). Low job satisfaction was also observed among PTE men from Continental Europe (20-30 hours/week, OR adj $1.80,95 \%$ CI 1.08-3.00; 5-19 hours/week, OR adj $3.61,95 \%$ CI 2.14-6.09), and Southern Europe regions (5-19 hours/week, $\mathrm{OR}_{\text {adj }} 2.98,95 \%$ CI 1.80-4.94). PTE men in Continental Europe experienced health status affected by work (20-30 hours/week, $\mathrm{OR}_{\text {adj }} 2.36,95 \%$ CI 1.55-3.58; 5-19 hours/week, $\mathrm{OR}_{\mathrm{adj}}$ $2.53,95 \%$ CI 1.54-4.14), but health status for those in PTE was not affected among men from Eastern Europe and women from Scandinavia and The Netherlands.

Regarding psychosocial problems, the most consistent finding is that, among women, working 5-19 hours/ week is associated with less work-related stress and psychological distress in most regions (except Eastern Europe and the Anglo-Saxon countries). For those working 20-30 hours/week, less work-related stress was only found among females from Scandinavia and The Netherlands. Among men, work-related stress was observed among those in PTE in Continental and Southern Europe who worked 5-19 hours/week (results for Anglo-Saxon welfare type are omitted as a result of too few cases).

After additional adjustment for working conditions (table 4), with respect to the results described above (table 3), the associations between length of working hours (PTE/FTE) and low job satisfaction disappear among Southern European women, but remain among Continental (20-30 hours/week, $\mathrm{OR}_{\text {adj }} 2.17,95 \% \mathrm{CI}$ $1.19-3.92$; 5-19 hours/week, $\mathrm{OR}_{\text {adj }} 2.86,95 \%$ CI $1.53-$ 5.34) and Southern (5-19 hours/week, $\mathrm{OR}_{\text {adj }} 2.44,95 \%$ CI 1.36-4.39) European men. The association with health affected by work also remains for Continental European men (20-30 hours/week, $\mathrm{OR}_{\text {adj }} 2.66,95 \%$ CI 1.70-4.16; 5-19 hours/week, $\mathrm{OR}_{\text {adj }} 2.02,95 \% \mathrm{CI}$ 1.19-3.43). For psychosocial problems among both men and women, additional adjustment for working 
Table 1. General description of the population by sex and region. Salaried workers aged 16-64 years working 5-40 hours per week. Pvalues compare men and women in each region. Data are from the Fourth Europen Working Condition Survey, 2005.

\begin{tabular}{|c|c|c|c|c|c|c|c|c|c|c|}
\hline & \multicolumn{2}{|c|}{$\begin{array}{l}\text { Scandinavia and } \\
\text { The Netherlands }\end{array}$} & \multicolumn{2}{|c|}{$\begin{array}{l}\text { Continental } \\
\text { Europe }\end{array}$} & \multicolumn{2}{|c|}{$\begin{array}{l}\text { Southern } \\
\text { Europe }\end{array}$} & \multicolumn{2}{|c|}{$\begin{array}{l}\text { Eastern } \\
\text { Europe }\end{array}$} & \multicolumn{2}{|c|}{$\begin{array}{l}\text { Anglo-Saxon } \\
\text { countries }\end{array}$} \\
\hline & $\begin{array}{l}\text { Men a }^{\mathrm{a}} \\
(\mathrm{N}=793)\end{array}$ & $\begin{array}{l}\text { Women }^{b} \\
(\mathrm{~N}=834)\end{array}$ & $\begin{array}{c}\text { Men }^{\text {a }} \\
(\mathrm{N}=3031)\end{array}$ & $\begin{array}{l}\text { Women }{ }^{b} \\
(N=3139)\end{array}$ & $\begin{array}{l}\text { Men }^{a} \\
(N=1882)\end{array}$ & $\begin{array}{l}\text { Women }^{b} \\
(N=1631)\end{array}$ & $\begin{array}{c}\text { Men a }^{\mathrm{a}} \\
(\mathrm{N}=1141)\end{array}$ & $\begin{array}{l}\text { Women }^{b} \\
(N=1278)\end{array}$ & $\begin{array}{c}\text { Men a } \\
(N=1074)\end{array}$ & $\begin{array}{l}\text { Women }{ }^{b} \\
(N=1338)\end{array}$ \\
\hline & $\%$ & $\%$ & $\%$ & $\%$ & $\%$ & $\%$ & $\%$ & $\%$ & $\%$ & $\%$ \\
\hline \multicolumn{11}{|l|}{ Full- and part-time work (hours) } \\
\hline $31-40$ & 88.2 & $57.0^{\mathrm{c}}$ & 93.5 & $68.9^{c}$ & 88.4 & $60.4^{c}$ & 88.2 & $81.2^{\mathrm{c}}$ & 87.1 & $43.1^{c} \mathrm{c}-\mathrm{cos}(\mathrm{c}) \mathrm{c}$ \\
\hline $20-30$ & 7.6 & 27.1 & 3.7 & 21.0 & 7.8 & 30.0 & 6.2 & 13.8 & 5.6 & 32.9 \\
\hline $5-19$ & 4.2 & 15.9 & 2.8 & 10.1 & 3.8 & 9.6 & 5.6 & 5.0 & 7.3 & 24.0 \\
\hline \multicolumn{11}{|l|}{ Working and employment conditions } \\
\hline High job demands & 45.1 & 48.8 & 48.3 & $42.1^{d}$ & 52.5 & $37.5^{c}$ & 41.0 & 40.8 & 47.0 & $37.7^{\mathrm{d}}$ \\
\hline Low control & 16.6 & $21.4^{\mathrm{e}}$ & 39.6 & 40.3 & 40.2 & 41.7 & 42.0 & 37.5 & 38.6 & 36.9 \\
\hline Low support & 10.1 & 12.3 & 35.1 & 38.9 & 35.5 & 39.2 & 19.5 & 22.5 & 21.4 & 16.9 \\
\hline Low salary & 25.2 & $37.3^{\mathrm{c}}$ & 19.4 & $31.7^{c}$ & 29.6 & 33.9 & 41.4 & $46.6^{d}$ & 23.2 & $31.5^{d}$ \\
\hline Low promotion & 43.8 & $53.5^{c}$ & 41.9 & 48.9 e & 47.9 & 53.3 & 49.9 & $57.0^{\mathrm{e}}$ & 34.9 & 35.7 \\
\hline Temporary contract & 17.1 & 19.4 & 13.0 & 14.4 & 20.5 & $33.5^{c}$ & 20.8 & 20.7 & 35.5 & 30.9 \\
\hline \multicolumn{11}{|l|}{$\begin{array}{l}\text { Job satisfaction, health status, and } \\
\text { psychosocial problems }\end{array}$} \\
\hline Low job satisfaction & 12.6 & 12.2 & 11.9 & 14.3 & 27.6 & $21.3^{d}$ & 24.3 & $19.5^{d}$ & 8.6 & 6.6 \\
\hline Health affected by work & 37.9 & 35.0 & 24.2 & 22.5 & 39.8 & 34.5 & 49.1 & 46.7 & 13.7 & 17.4 \\
\hline Work-related stress & 23.0 & 23.2 & 14.8 & 17.1 & 28.3 & 24.6 & 27.2 & 29.5 & 6.7 & 10.3 \\
\hline Work-related psychological distress & 23.4 & 21.2 & 15.4 & 16.1 & 31.4 & 27.7 & 38.8 & 36.9 & 6.4 & 10.7 \\
\hline \multicolumn{11}{|l|}{ Job category } \\
\hline Upper & 37.5 & $43.1^{\mathrm{c}}$ & 33.3 & $39.5^{c}$ & 23.4 & $38.3^{c}$ & 22.1 & $42.0^{c}$ & 33.8 & $38.6^{c}$ \\
\hline Medium & 19.4 & 39.0 & 16.8 & 41.3 & 24.7 & 33.7 & 14.3 & 26.9 & 28.4 & 47.9 \\
\hline Lower & 41.1 & 16.9 & 47.9 & 18.4 & 49.3 & 27.6 & 61.3 & 30.5 & 36.5 & 12.5 \\
\hline Married or cohabiting & 72.0 & 69.2 & 69.7 & $63.9 \mathrm{~d}$ & 70.0 & 59.4 & 72.2 & 69.6 & 63.6 & 69.9 \\
\hline \multicolumn{11}{|l|}{ Having young children ( $\leq 3$ years) } \\
\hline 0 & 89.7 & 88.2 & 92.1 & $94.6^{d}$ & 91.7 & 90.8 & 89.9 & $94.5^{\mathrm{e}}$ & 89.3 & 90.3 \\
\hline$\geq 1$ & 10.3 & 10.8 & 7.9 & 5.4 & 8.3 & 9.2 & 10.1 & 5.5 & 10.7 & 9.7 \\
\hline
\end{tabular}

a Mean age (standard deviation): Scandinavian and The Netherlands: 40 (12.3) years; Continental Europe: 39.2 (11.2); Southern Europe: 38.1 (11.2);

Eastern Europe: 389.5 (11.5); Anglo-Saxon countries: 38.4 (12.4).

${ }^{b}$ Mean age (standard deviation): Scandinavian and The Netherlands: 39.7 (11.8) years; Continental Europe: 39.7 (11.0); Southern Europe: 37.7 (10.8);

Eastern Europe: 39.5 (10.4); Anglo-Saxon countries: 38.7 (12.0).

${ }^{c} \mathrm{P}<0.001$.

d $P<0.05$.

e $\mathrm{P}<0.01$.

conditions does not change the direction of the baseline associations across welfare states regimes.

\section{Discussion}

Our aim was to analyze the differences in working conditions between FTE and PTE and understand how FTE and PTE workers differ in terms of job satisfaction, health status, and work-related psychosocial problems. Finally, we also explored the role of working conditions as a potential modifier of this association, stratified by gender and welfare state regime. Data were obtained from the $4^{\text {th }}$ European Working Conditions Survey carried out in 2005, and salaried workers aged 16-64 years who worked $\leq 40$ hours per week were included.

In contrast to the objectives of the EU Directive on equal treatment for part-time workers (97/81/EC) (27), PTE continues to be associated with adverse working conditions, although our results show that this does not translate into a systematic relationship between PTE and low job satisfaction, having one's health affected by work, or work-related psychosocial problems, either generally or as a function of gender or type of welfare state. We would argue that this "PTE paradox" can be partly explained by the conjunction of three vectors: the trade-off between job demands and other (adverse) working conditions, the gender division of labor, and personal preferences and the social norms embedded in different welfare states regimes.

For women, this paradox may be partly due to PTE having lower psychological job demands than FTE and PTE workers being less exposed to adverse working conditions. In addition, in the context of the sexual division of labor, the inverse association between PTE and psychosocial problems observed among women may come from an ability to effectively combine work and family life. However, notwithstanding the lower salary and poorer chances of promotion associated with 
Table 2. Association between full- and part-time emplyment and adverse working and emplyment conditions compared to non-adverse conditions, stratified by sex and region. Adjusted odds ratio $\left(\mathrm{OR}_{\mathrm{adj}}\right)$ and $95 \%$ confidence intervals $(95 \% \mathrm{Cl})$ for age, number of children, marital status and job category. Data are from the Fourth European Working Condition Survey, 2005,

\begin{tabular}{|c|c|c|c|c|c|c|c|c|c|c|c|c|c|c|c|c|}
\hline \multirow[t]{2}{*}{ Hours } & \multicolumn{3}{|c|}{$\begin{array}{l}\text { Scandinavia and } \\
\text { The Netherlands }\end{array}$} & \multicolumn{4}{|c|}{$\begin{array}{l}\text { Continental } \\
\text { Europe }\end{array}$} & \multicolumn{3}{|c|}{$\begin{array}{c}\text { Southern } \\
\text { Europe }\end{array}$} & \multicolumn{3}{|c|}{$\begin{array}{l}\text { Eastern } \\
\text { Europe }\end{array}$} & \multicolumn{3}{|c|}{$\begin{array}{l}\text { Anglo-Saxon } \\
\text { countries }\end{array}$} \\
\hline & $\mathrm{N} \%$ & $\mathrm{OR}_{\mathrm{adj}}$ & $95 \% \mathrm{Cl}$ & $\mathrm{N}$ & $\%$ & $\mathrm{OR}_{\mathrm{adj}}$ & $95 \% \mathrm{Cl}$ & N $\%$ & $O R_{\text {adj }}$ & $95 \% \mathrm{Cl}$ & $\mathrm{N} \quad \%$ & $0 R_{a d} j$ & $95 \% \mathrm{Cl}$ & N $\%$ & $\mathrm{OR}_{\mathrm{adj}}$ & $95 \% \mathrm{Cl}$ \\
\hline$\overline{M e n}$ & \multicolumn{2}{|l|}{793} & & \multicolumn{3}{|c|}{3031} & & \multicolumn{2}{|l|}{1882} & & \multicolumn{2}{|l|}{1141} & & \multicolumn{2}{|l|}{1074} & \\
\hline \multicolumn{17}{|l|}{$\begin{array}{l}\text { High job } \\
\text { demands }\end{array}$} \\
\hline $31-40$ & 46.8 & $1.00^{\mathrm{a}}$ & & & 48.4 & $1.00^{a}$ & & 52.8 & 1.00 & & 42.3 & $3.00^{a}$ & & 46.4 & 41.00 & \\
\hline $20-30$ & 33.6 & 0.60 & $0.34-1.07$ & & 31.1 & 0.54 & $0.36-0.82^{b}$ & 52.8 & 1.06 & $0.75-1.51$ & 32.8 & 0.60 & $0.34-1.06$ & 55.8 & 81.89 & $1.08-3.31^{\circ}$ \\
\hline $5-19$ & 31.8 & 0.39 & $0.18-0.86^{c}$ & & 67.5 & 2.89 & $1.79-4.66^{\mathrm{d}}$ & 44.4 & 0.81 & $0.50-1.33$ & 29.1 & 0.60 & $0.33-1.05$ & 47.7 & $7 \quad 0.69$ & $0.40-1.16$ \\
\hline \multicolumn{17}{|c|}{ Low control } \\
\hline $31-40$ & 14.4 & $1.00^{\mathrm{e}}$ & & & 38.9 & $1.00^{\mathrm{e}}$ & & 40.3 & $1.00^{a}$ & & 41.2 & $1.00^{\mathrm{a}}$ & & 37.4 & $41.00^{f}$ & \\
\hline $20-30$ & 28.2 & 2.30 & $1.21-4.34^{c}$ & & 48.9 & 2.04 & $1.35-3.07^{\mathrm{d}}$ & 34.7 & 1.07 & $0.72-1.57$ & 50.3 & 2.06 & $1.19-3.57^{c}$ & 27.6 & 60.67 & $0.36-1.24$ \\
\hline $5-19$ & 41.9 & 2.85 & $1.29-6.30^{c}$ & & 48.4 & 2.14 & $1.33-3.44^{b}$ & 46.1 & 2.03 & $1.21-3.41^{b}$ & 45.8 & 31.52 & $0.86-2.67$ & 61.3 & 32.60 & $1.50-4.49^{\circ}$ \\
\hline \multicolumn{17}{|c|}{ Low support } \\
\hline $31-40$ & 9.9 & 1.00 & & & 35.4 & 1.00 & & 35.6 & 1.00 & & 18.4 & $+1.00^{t}$ & & 19.5 & 51.00 & \\
\hline $20-30$ & 15.0 & 1.77 & $0.81-3.85$ & & 21.4 & 0.46 & $0.29-0.74^{b}$ & 25.7 & 0.72 & $0.48-1.07$ & 25.7 & 71.78 & $0.99-3.17$ & 51.1 & 13.54 & $2.02-6.21^{\mathrm{d}}$ \\
\hline $5-19$ & 6.8 & 1.03 & $0.25-4.29$ & & 44.9 & 1.48 & $0.94-2.32$ & 53.0 & 2.29 & $1.41-3.73^{d}$ & 29.6 & 2.10 & $1.18-3.72^{\mathrm{c}}$ & 21.2 & 20.96 & $0.51-1.81$ \\
\hline \multicolumn{17}{|c|}{ Low salary } \\
\hline $31-40$ & 25.3 & 1.00 & & & 19.6 & 1.00 & & 28.6 & $1.00^{\mathrm{e}}$ & & 42.4 & 1.00 & & 21.3 & $31.00^{a}$ & \\
\hline $20-30$ & 27.7 & 1.11 & $0.60-2.03$ & & 15.2 & 0.72 & $0.42-1.22$ & 34.1 & 1.48 & $1.02-2.14^{c}$ & 40.3 & 1.18 & $0.70-1.98$ & 37.1 & 11.60 & $0.90-2.85$ \\
\hline $5-19$ & 19.2 & 0.75 & $0.30-1.87$ & & 19.5 & 1.07 & $0.61-1.89$ & 44.2 & 2.12 & $1.29-3.45^{b}$ & 26.5 & 0.52 & $0.29-0.92^{c}$ & 34.6 & 61.56 & $0.89-2.73$ \\
\hline $\begin{array}{l}\text { Low } \\
\text { promotio }\end{array}$ & & & & & & & & & & & & & & & & \\
\hline $31-40$ & 41.1 & $1.00^{e}$ & & & 42.0 & $1.00^{a}$ & & 47.1 & $1.00^{\mathrm{e}}$ & & 50.0 & $1.00^{a}$ & & 33.6 & $61.00^{f}$ & \\
\hline 20-30 & 70.0 & 3.91 & $2.09-7.30^{d}$ & & 39.1 & 1.25 & $0.83-1.88$ & 46.2 & 1.61 & $1.12-2.32^{b}$ & 55.2 & 2.48 & $0.87-2.52$ & 54.8 & 81.66 & $0.93-2.98$ \\
\hline $5-19$ & 52.9 & 2.26 & $1.03-4.96^{c}$ & & 41.9 & 1.75 & $1.08-2.83^{c}$ & 71.6 & 4.08 & $2.35-7.09^{d}$ & 57.8 & 1.63 & $0.93-2.86$ & 35.5 & 52.30 & $1.29-4.09^{b}$ \\
\hline $\begin{array}{l}\text { Temporar } \\
\text { contract }\end{array}$ & & & & & & & & & & & & & & & & \\
\hline $31-40$ & 14.6 & $1.00^{f}$ & & & 11.8 & $1.00^{\mathrm{e}}$ & & 17.1 & $1.00^{\mathrm{e}}$ & & 17.2 & $2.00^{\mathrm{e}}$ & & 32.8 & $81.00^{f}$ & \\
\hline $20-30$ & 23.4 & 1.45 & $0.73-2.90$ & & 31.0 & 3.38 & $2.12-5.39^{d}$ & 50.7 & 4.67 & $3.10-7.04^{d}$ & 52.2 & 5.79 & $3.30-10.17^{d}$ & 63.1 & 13.73 & $2.07-6.71^{d}$ \\
\hline $5-19$ & 59.0 & 3.65 & $1.61-8.24^{b}$ & & 27.1 & 2.30 & $1.34-3.94^{b}$ & 37.4 & 3.88 & $2.17-6.93^{d}$ & 42.8 & 4.87 & $2.69-8.79^{d}$ & 47.1 & 11.37 & $0.78-2.41$ \\
\hline Women & 834 & & & 3139 & & & & 1631 & & & 1278 & & & 1338 & & \\
\hline $\begin{array}{l}\text { High job } \\
\text { demands }\end{array}$ & & & & & & & & & & & & & & & & \\
\hline $31-40$ & 54.7 & $1.00^{\mathrm{e}}$ & & & 45.7 & $1.00^{\mathrm{e}}$ & & 42.7 & $1.00^{\mathrm{e}}$ & & 43.8 & $31.00^{\mathrm{e}}$ & & 45.4 & $41.00^{e}$ & \\
\hline $20-30$ & 43.5 & 0.62 & $0.44-0.85^{b}$ & & 39.9 & 0.82 & $0.68-0.98^{c}$ & 31.5 & 0.65 & $0.52-0.82^{\mathrm{d}}$ & 26.4 & 0.51 & $0.35-0.73^{d}$ & 36.7 & 70.77 & $0.59-0.99^{\circ}$ \\
\hline $5-19$ & 36.6 & 0.47 & $0.31-0.72^{\mathrm{d}}$ & & 21.7 & 0.30 & $0.23-0.41^{\mathrm{d}}$ & 23.3 & 0.43 & $0.29-0.65^{d}$ & 30.4 & 0.54 & $0.31-0.94^{c}$ & 25.2 & 20.43 & $0.31-0.60^{\circ}$ \\
\hline Low cont & & & & & & & & & & & & & & & & \\
\hline $31-40$ & 20.1 & 1.00 & & & 38.3 & $1.00^{\mathrm{a}}$ & & 41.9 & $1.00^{\mathrm{e}}$ & & 38.0 & 1.00 & & 31.2 & $21.00^{\mathrm{a}}$ & \\
\hline $20-30$ & 21.5 & 1.09 & $0.73-1.64$ & & 43.7 & 1.15 & $0.96-1.38$ & 36.3 & 0.95 & $0.75-1.21$ & 31.5 & 0.91 & $0.62-1.31$ & 39.2 & 21.28 & $0.97-1.69$ \\
\hline 5-19 & 26.1 & 1.01 & $0.62-1.65$ & & 46.7 & 1.34 & $1.04-1.72^{c}$ & 57.5 & 2.63 & $1.81-3.82^{\mathrm{d}}$ & 45.0 & 1.37 & $0.80-2.37$ & 44.2 & 21.37 & $1.00-1.88^{c}$ \\
\hline Low su & & & & & & & & & & & & & & & & \\
\hline $31-40$ & 10.4 & 1.00 & & & 36.9 & $1.00^{\mathrm{a}}$ & & 33.3 & $1.00^{\mathrm{e}}$ & & 22.1 & 1.00 & & 11.8 & 81.00 & \\
\hline $20-30$ & 15.1 & 1.35 & $0.83-2.21$ & & 41.6 & 1.09 & $0.90-1.31$ & 44.1 & 1.98 & $1.56-2.52^{d}$ & 25.2 & 1.31 & $0.8 \mathrm{~s}$ & 19.5 & 51.53 & $1.06-2.21^{\circ}$ \\
\hline 5-19 & 14.5 & 1.65 & $0.90-3.01$ & & 47.1 & 1.34 & $1.04-1.72^{c}$ & 61.5 & 4.48 & $3.07-6.54^{d}$ & 20.6 & 0.93 & $0.50-1.76$ & 22.5 & 51.20 & $0.79-1.81$ \\
\hline Low salar & & & & & & & & & & & & & & & & \\
\hline $31-40$ & 41.6 & $1.00^{f}$ & & & 30.6 & 1.00 & & 29.9 & $1.00^{\mathrm{e}}$ & & 46.0 & 1.00 & & 27.7 & 71.00 & \\
\hline $20-30$ & 33.5 & 0.70 & $0.50-0.99 c$ & & 35.0 & 1.17 & $0.97-1.41$ & 38.3 & 1.51 & $1.19-1.92^{d}$ & 48.9 & 1.21 & $0.87-1.68$ & 37.8 & 81.47 & $1.11-1.93^{b}$ \\
\hline $5-19$ & 28.3 & 0.59 & $0.38-0.92^{c}$ & & 32.3 & 0.98 & $0.76-1.28$ & 44.7 & 2.20 & $1.54-3.14^{d}$ & 49.7 & 7.24 & $0.74-2.08$ & 29.8 & 81.11 & $0.80-1.54$ \\
\hline $\begin{array}{l}\text { Low } \\
\text { promoti }\end{array}$ & & & & & & & & & & & & & & & & \\
\hline $31-40$ & 47.0 & $1.00^{\mathrm{e}}$ & & & 44.4 & $1.00^{\mathrm{e}}$ & & 46.5 & $1.00^{\mathrm{e}}$ & & 56.4 & $41.00^{a}$ & & 27.6 & $61.00^{e}$ & \\
\hline $20-30$ & 55.5 & 1.36 & $0.97-1.90$ & & 55.1 & 1.33 & $1.10-1.60^{b}$ & 63.1 & 2.56 & $2.00-3.27^{d}$ & 58.0 & 1.43 & $1.00-2.02^{c}$ & 35.8 & 81.26 & $0.95-1.68$ \\
\hline $5-19$ & 73.1 & 3.22 & $2.04-5.10^{d}$ & & 67.4 & 2.11 & $1.62-2.75^{d}$ & 65.0 & 2.93 & $1.99-4.28^{d}$ & 62.6 & 1.47 & $0.84-2.56$ & 50.1 & 11.79 & $1.30-2.47^{\circ}$ \\
\hline $\begin{array}{l}\text { Tempor } \\
\text { contract }\end{array}$ & & & & & & & & & & & & & & & & \\
\hline $31-40$ & 16.8 & 1.00 & & & 11.7 & $1.00^{\mathrm{e}}$ & & 28.3 & $1.00^{e}$ & & 17.5 & $51.00^{e}$ & & 27.4 & $41.00^{f}$ & \\
\hline 20-30 & 19.1 & 1.24 & $0.81-1.93$ & & 20.1 & 2.32 & $1.80-2.99^{d}$ & 36.7 & 1.89 & $1.46-$ & 29.1 & 2.13 & 1.45 & 29.4 & 41.00 & $0.75-1.34$ \\
\hline 5-19 & 29.2 & 1.42 & $0.86-2.34$ & & 21.2 & 2.29 & $1.64-3.21^{\mathrm{d}}$ & 55.9 & 5.68 & $3.80-8.46^{d}$ & 47.9 & 4.55 & $2.64-7.85^{d}$ & 39.1 & 11.63 & $1.18-2.25^{b}$ \\
\hline
\end{tabular}


Table 3. Association between full- and part-time employment and low job satisfaction, having one's health status affected by work, and having psychosocial work-related problems, compared with high job satisfaction, not having one's health status affected by work and not having psychosocial work-related problems, stratified by sex and region. Adjusted Odds ratio $\left(0 \mathrm{R}_{\mathrm{adj}}\right)$ and $95 \%$ confidence intervals $(95 \%$ Cl) for age, number of children, marital status and job category. Data are from the Fourth European Working Conditions Survey, 2005.

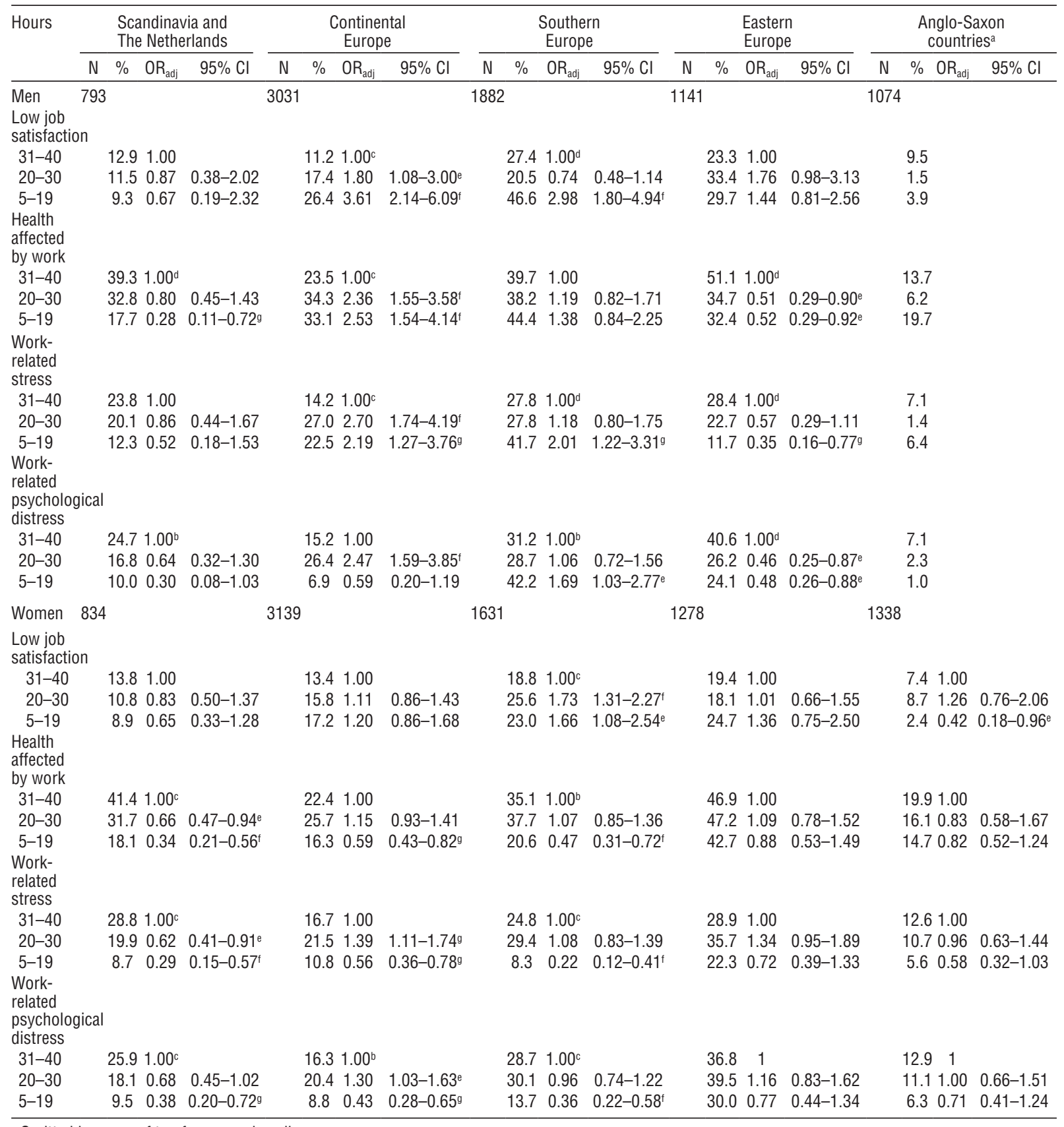

a Omitted because of too few cases in cells.

b Wald test with $\mathrm{P}<0.05$.

c Wald test with $\mathrm{P}<0.001$.

d Wald test with $P<0.01$.

e $\mathrm{P}<0.05$.

${ }^{f} P<0.001$

$g \mathrm{P}<0.01$. 
Table 4. Association of full- and part-time employment with low job satisfaction, health status affected by work and having psychosocial work-related problems compared with high job satisfaction, health status not affected by work and not having psychosocial work-related problems by sex and region. Adjusted odds ratio $\left(\mathrm{OR}_{\mathrm{adj}}\right)$ and $95 \%$ confidence intervals $(95 \% \mathrm{CI})$ for age, number of children, marital status, job category, and working and employment conditions. Data are from the Fourth European Working Conditions Survey, 2005.

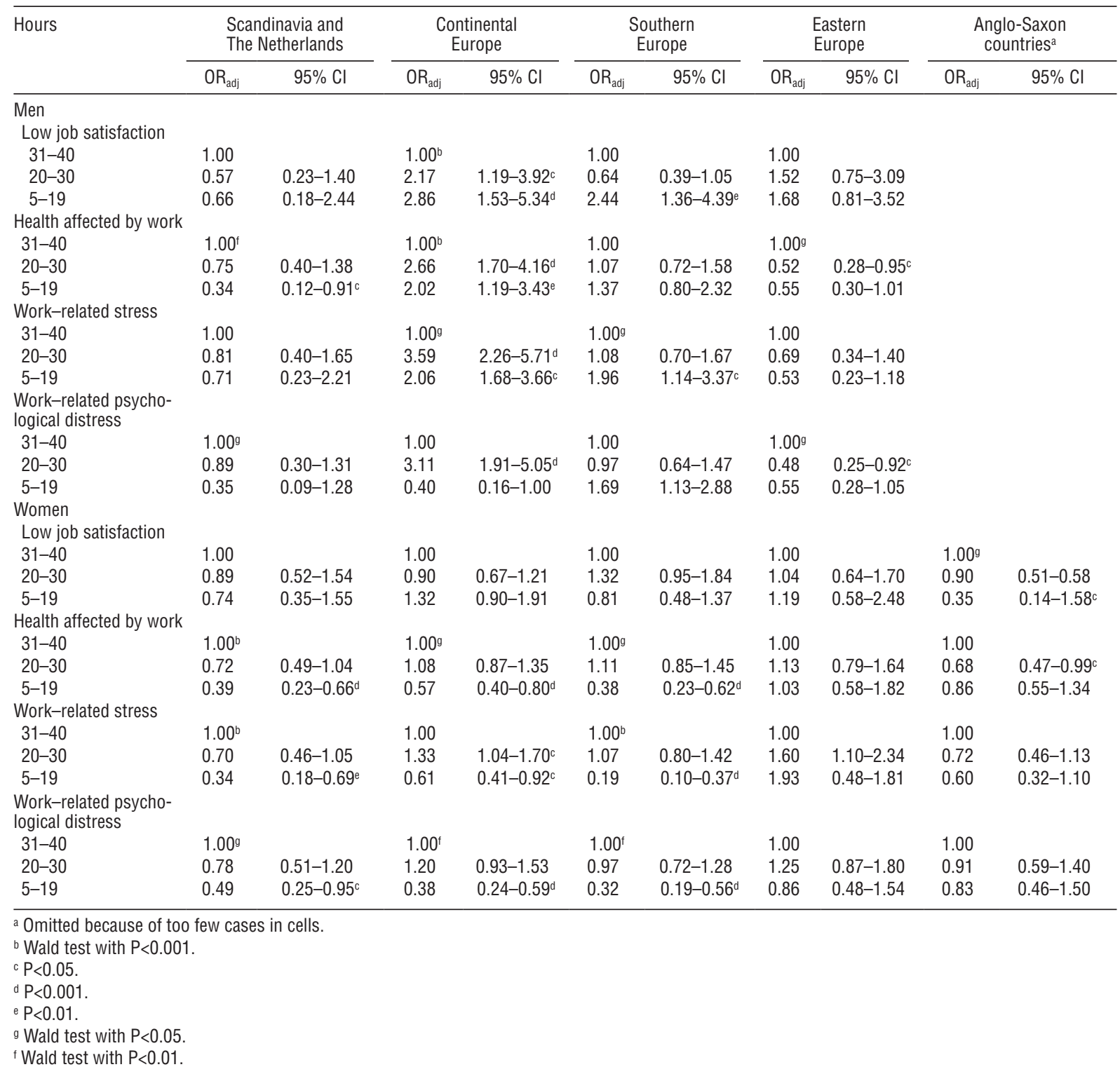

PTE, the ability of PTE women to balance work and family life, and the consequences of this for their health are conditioned by the different levels of their work responsibilities interfering with their family life (28). In addition, our study shows that low job satisfaction among women from Southern Europe is accounted for by working conditions.

For men, the PTE paradox is true for those from Scandinavia and The Netherlands, although the acceptance of PTE by men in countries like The Netherlands, either by norms and social preferences $(29,30)$ or embedded in the culture of industrial relations (31), has previously been highlighted. In contrast, PTE is least common among men in Continental European countries, which may reflect cultural restrictions on the acceptance of men not being the main breadwinner (3), moreover, the group which works $<20$ hours/week is the only group to report greater job demands. Low job satisfaction among Southern European men working $<20$ hours/ week may arise because lower psychological demands may be offset by the poorer working conditions. Due to lack of data, we are unable to present corresponding results for Anglo-Saxon men.

Welfare state regime modulates the association 
between job satisfaction, health status, and psychosocial problems and working hours, such that PTE is not associated with psychosocial problems among men and is inversely associated among women, especially those in the region where PTE is most common, ie, Scandinavia and The Netherlands. Sweden, Norway, and The Netherlands are among the most flexible countries in the regulation of PTE working conditions, whether for reasons related to caregiving, automatic reversion from PTE to FTE, or unemployment rights (32). Therefore access to and type of PTE is conditioned not only by personal choice, but also by regulation and the implementation of non-discriminatory practices. Several studies have highlighted the importance of active labor market policies to promote equal treatment between PTE and FTE working conditions (33-35).

PTE can be voluntary or involuntary and used as a mechanism to engage unemployed workers in the labor market. But equally it can be a "labor trap", characterized by low wages and poor benefits, typified by the so-called "mini-jobs" that have become especially common in Germany and may be adopted in other European countries. Stratifying our results by country (data not shown), we find that Germany has the highest rate of low job satisfaction (and also poor health status and higher work-related psychosocial problems) among men after controlling for working conditions $\left(\mathrm{OR}_{\text {adj }} 6.46,95 \% \mathrm{CI}\right.$ 2.82-14.78).

\section{Limitations}

The main limitation of this study may be its crosssectional design, which cannot discard the possibility of reverse causation, whereby people with poor health status and more psychosocial problems are more likely to be in PTE. However, we would then expect this general pattern to be evident in most welfare typologies, which is not the case.

The EWCS questions dealing with health status and work-related psychosocial problems have not been validated. However, previous studies have demonstrated the validity of a single-item measure of stress-symptoms (23), and our scale for measuring psychosocial distress showed good reliability. Finally, although our derived welfare typology for analyzing PTE/FTE differences is a justified classification in capturing fundamental betweencountry differences (36), a larger sample size would help to disentangle this relationship in the context of specific family support and labor policies at the national level.

\section{Concluding remarks}

PTE is associated with poorer working conditions than FTE. However, we did not observe a systematic relationship between PTE and job satisfaction, health status, or psychosocial problems across welfare state regimes. PTE or "mini-jobs" in Continental and Southern European welfare state regimes, respectively, is associated with lower job satisfaction, poorer health status and higher work-related psychosocial problems among men, even after controlling for working conditions, which highlights the important role of social norms that form part of different welfare states regimes. Low job satisfaction among PTE women from Southern Europe may be explained by the poorer working conditions. As the frequency of PTE increases, employment relations should promote effective measures to ensure equal treatment between full- and part-time workers. However, in most welfare state regimes PTE women who work fewer hours generally have lower work-related psychosocial problems.

\section{References}

1. Buddelmeyer H, Mourre G, Ward M. Why do europeans work Part-time? A cross-country panel analysis. Res Labor E. 2008;28:81-139. http://dx.doi.org/10.1016/S01479121(08)28004-0.

2. Statistical Office of the European Communities. Labour market. Employment-LFS adjusted series. Persons employed part-time [accessed: 12th april 2012]: http://epp.eurostat. ec.europa.eu/portal/page/portal/statistics/search_database.

3. Artazcoz L, Cortes I, Escriba-Aguir V, Bartoll X, Basart $\mathrm{H}$, Borrell C. Long working hours and health status among employees in Europe: between-country differences. Scand J Work Environ Health. 2013;39(4):369-78. http://dx.doi. org/10.5271/sjweh.3333.

4. Pfau-Effinger B. Socio-historical paths of the male breadwinner model - an explanation of cross-national differences. Br J Sociol. 2004;55:377-93. http://dx.doi. org/10.1111/j.1468-4446.2004.00025.x.

5. Pfau-Effinger B. Welfare state policies and the development of care arrangements. European Societies. 2005;7:321-47. http:// dx.doi.org/10.1080/14616690500083592.

6. Virtanen M, Kivimaki M, Joensuu M, Virtanen P, Elovainio M, Vahtera J. Temporary employment and health: a review. Int J Epid emiol. 2005;34(3):610-22. http://dx.doi.org/10.1093/ ije/dyi024.

7. Manning A, Petrongolo B. The Part-Time Pay Penalty for Women in Britain. Econ J. 2008; 118:28-51. http://dx.doi. org/10.1111/j.1468-0297.2007.02115.x.

8. O'Dorchai D, Plasman R, Rycx, F . The part-time wage penalty in European countries: how large is it for men? Int J Manpower. 2007;28(7):571-603. http://dx.doi. org/10.1108/01437720710830061.

9. Bardasi E, Gornik. Working for less? Women's part-time wage penalties across countries. Fem Econ. 2008;14(1):37-72. http://dx.doi.org/10.1080/13545700701716649. 
10. Quinlan M, Mayhew C, Bohle P. The global expansion of precarious employment, work disorganization, and consequences for occupational health: a review of recent research. Int J Health Serv. 2001;31(2):335-414. http://dx.doi. org/10.2190/607H-TTV0-QCN6-YLT4.

11. Benavides FG, Benach J, Diez-Roux AV, Roman C. How do types of employment relate to health indicators? Findings from the second European survey on working conditions. J Epidemiol Commun H. 2000;54(7):494-501. http://dx.doi. org/10.1136/jech.54.7.494.

12. Joyce K, Pabayo R, Critchley JA, Bambra C. Flexible working conditions and their effects on employee health and wellbeing. Cochrane Database Syst Rev. 2010;(2): pub2. http://dx.doi. org/10.1002/14651858.CD008009.

13. Dooley D, Prause J, Ham-Rowbottom KA. Underemployment and depression: longitudinal relationships. J Health Soc Behav. 2000;41(4):421-36. http://dx.doi.org/10.2307/2676295.

14. Rodriguez E. Marginal employment and health in Britain and Germany: does unstable employment predict health? Soc Sci Med. 2002;55(6):963-79. http://dx.doi.org/10.1016/S02779536(01)00234-9.

15. Bardasi E, Francesconi M. The impact of atypical employment on individual wellbeing: evidence from a panel of British workers. Soc Sci Med. 2004;58(9):1671-88. http://dx.doi. org/10.1016/S0277-9536(03)00400-3.

16. European Foundation for the Improvement of Working and Living Conditions. Fourth European Working Conditions Survey. Dublin: European Foundation for the Improvement of Working and Living Conditions; 2007.

17. European Foundation for the Improvement of Working and Living Conditions. Quality report of the 4th European working conditions survey. Luxemburg: Office for Official Publications of the European Communities; 2007.

18. Part-time work. Report V (1). International Labour Conference, 80th Session. Geneva:1993.

19 Bastelaer A, Lemaitre A, Marianna P. The Definition of Parttime Work for the Purpose of International Comparisons. Labour Market and Social Policy Occasional Papers. Paris: Organisation for Economic Co-operation and Development; 1997.

20. Karasek R, Theorell T. Healthy work: stress, productivity, and the reconstruction of working life. New York: Basic Books; 1990.

21. Siegrist J, Starke D, Chandola T, Godin I, Marmot M, Niedhammer I, et al. The measurement of effort-reward imbalance at work: European comparisons. Soc Sci Med. 2004 Apr;58(8):1483-99. http://dx.doi.org/10.1016/S02779536(03)00351-4.

22. Gimeno D, Benavides FG, Amick BC, Benach J, Martinez JM. Psychosocial factors and work related sickness absence among permanent and non-permanent employees. J Epidemiol Commun H. 2004;58(10):870-6. http://dx.doi.org/10.1136/ jech.2003.016634.
23. Elo AL, Leppänen A, Jahkola J. Validity of a single-item measure of stress symptoms. Scand J Work Environ Health. 2003;29:444-51. http://dx.doi.org/10.5271/sjweh.752.

24. Esping-Anderson G. The three worlds of capitalism. London: Polity; 1990.

25. Parent-Thirion A, Fernández E, Hurley J, Vermeylen G. Fourth European Working Conditions Survey. Luxemburg: Office fro Official for Publications of the European Communities; 2007.

26. Eikemo TA, Bambra C, Judge K, Rindgal K. Welfare state regimes and differences in self-perceived health in Europe: A multilevel analysis. Soc Sci Med. 2008;66:2281-95. http:// dx.doi.org/10.1016/j.socscimed.2008.01.022.

27. Council Directive 97/81/CE of 15.12 .1997 concerning the Framework Agreement on part-time. Official Journal L 014. 20/01/1998;9-14

28. Higgins C, Duxbury L, Lea K. Part-time work for women: does it really help balance work and family? Hum Resourc Manage. 2000;39:17-32. http://dx.doi.org/10.1002/(SICI)1099050X(200021)39:1<17::AID-HRM3>3.0.CO;2-Y

29. Wielers R, Raven D. Part-time and work norms in the Netherlands. Eur Sociol Rev. 2013;29(1):105-13. http:// dx.doi.org/10.1093/esr/jcr043.

30. Bosch N, Deelen A, Euwals R. Is Part-time employment here to stay? Working hours of Dutch women over successive generations. Labour. 2010;24(1):35-54. http://dx.doi. org/10.1111/j.1467-9914.2010.00470.x.

31. Allaart P, Bellmann L. Reasons for part-time work: and empirical analysis for Germany and The Netherlans. Int J Manpower. 2007;28(7):557-70. http://dx.doi. org/10.1108/01437720710830052.

32. Organisation for economic co-operation and development. Employment Outlook. Moving beyond the job crises. Paris: Organisation for Economic Co-operation and Development; 2010 .

33. Hardony I, Schone P. The Part-time wage gap in Norway: How large is it Really?. Brit J Ind Relat. 2006 ;44(2):263-82. http:// dx.doi.org/10.1111/j.1467-8543.2006.00497.x.

34. Gash V. Preference or constraint? Part-time worker's transition in Denmark, France and the United Kingdom. Work Employ Soc. 2008;22(4):655-74. http://dx.doi. org/10.1177/0950017008096741.

35. Fouarge D, Muffels R. Working part-time in the British, German, and Dutch labor market: Scarring for the wage career? Z wirt soz. 2009;129(2):217-26.

36. Bambra C. Sifting the wheat from the chaff:A two-dimensional discriminant analysis of welfare state regime theory. Soc Policy Adm. 2007;41:1-28. http://dx.doi.org/10.1111/j.14679515.2007.00536.x.

Received for publication: 20 September 2013 